\title{
Note on the use of the public nuisance doctrine in 21 st century South African law
}

\section{Introduction}

Since the reception of the common law remedy of public nuisance into South African law during the late 19th century, it has been applied in what can be categorised as three series of cases: the first series dating from the late 19th century to 1943 (Queenstown Municipality $v$ Wiehan 1943 (EDL) 134); the second series consisting of only one case in 1975 (Von Moltke v Costa Aroesa (Pty) Ltd 1975 (1) SA 255 (C) (the Von Moltke case)); and a third series between 1989 and 2001 (in East London Western Districts Farmers' Association v Minister of Education and Development Aid 1989 (2) SA 63 (A) (East London case) the application for an interdict to abate a public nuisance as a result of an informal settlement was granted; Diepsloot Residents and Landowners Association and Another $v$ Administrator Transvaal 1993 (1) SA 577 (T); Diepsloot Residents and Landowners Association and Another v Administrator Transvaal 1993 (3) SA 49 (T); Diepsloot Residents and Landowners Association and Another $v$ Administrator Transvaal 1994 (3) SA 336 (A)). In the Diepsloot trilogy, an application for an interdict preventing the establishment of the formal settlement was denied after the court considered policy considerations; in Rademeyer and Others $v$ Western Districts Councils and Others 1998 (3) SA 1011 (SE), the application for an interdict to prevent the establishment of an informal settlement was denied because the

How to cite: Samuels 'Note on the use of the public nuisance doctrine in 21 st century South African law' 
occupiers of the informal settlement were protected as "occupiers" under the Extension of Security of Tenure Act 62 of 1997. In Three Rivers Ratepayers Association and Others v Northern Metropolitan 2000 (4) SA 377 (W) (Three Rivers case), an application for an interdict was granted after the local authority could not prove that it had taken reasonable steps to prevent a possible public nuisance caused by an informal settlement being established in the vicinity of the properties owned by the members of the Three Rivers Ratepayers Association. In Minister of Public Works and Others $v$ Kyalami Ridge Environmental Association and Another (Mukhwevho intervening) 2001 (3) SA 1151 (CC), the court denied an application for an interdict to prevent a temporary transit camp from being established in the vicinity of farms and residential areas. Amongst the arguments presented by the applicants, was that of a public nuisance being constituted, but no evidence could be given to support that argument and it failed in the Constitutional Court.

In the first series of cases, public nuisance was applied in line with its original aims, namely to protect the health and safety of the public in general (according to Spencer ("Public nuisance - a critical examination" 198948 Cambridge Law Review 55-84 56), public nuisance can be defined as "an act or omission that endangers the life, health, property, morals, or comfort of the public, or to obstruct the public in the exercise or enjoyment of rights common to all Her Majesty's subjects"). In an attempt to protect the wellbeing of the community at large, the remedy served as a means against infringements such as noise (in Champion $v$ Inspector of Police, Durban 192647 NPD 133 the appellant was convicted when he lawfully used a building for public entertainment purposes when prohibited from doing so by section 76 of the General By-Laws. Section 76 stated that "[n]o person being in any private premises within the borough shall make any noise or disturbances so as to be a public nuisance in the neighbourhood of such private premises"), keeping a brothel (in $R v$ Paulse (1892) 9 SC 423 the accused was convicted on the ground that his brothel was kept in such a manner that it constituted a public nuisance); and obstruction of a highway (in Putt $v$ Rex 1908 EDC 25 , the appellant erected gates across a main road. The court a quo found that the gates constituted a public nuisance). In essence, the important factors were that all these nuisances affected a public right relating to the protection of public health or safety and, importantly, that the nuisance originated on public rather than private land.

However, the second and third series of public nuisance cases were applied contrary to its original aims. Some of the courts in both the second and third series of public nuisance cases used the terms "private nuisance" and "public nuisance" interchangeably and failed to distinguish between the different requirements for the two distinct species of nuisance (for example in Three Rivers 380F Snyders J stated that the concept of public nuisance is similar to that of private nuisance, except for the public extent of the nuisance). Therefore, although the nuisance originated on private instead of public land, courts based their decisions on public instead of private nuisance. Furthermore, the public 
nuisance doctrine was applied as a mechanism to evict occupiers of informal settlements and in so doing circumvented eviction legislation such as the Extension of Security of Tenure Act 62 of 1997 (ESTA) and the Prevention of Illegal Eviction from Unlawful Occupation of Land Act 19 of 1998 (PIE) (before the enactment of the anti-eviction measures of ESTA and PIE, applicants could rely directly on section 26(3) of the Constitution. However, there is no case law - in which the public nuisance doctrine was applied - wherein section 26(3) was directly applied) as well as sections 26 (1), (2) and (3) of the Constitution of 1996.

Statutory nuisance systematically replaced the common law notion of public nuisance in South African law, as it did in English law. Because of the implementation of statutory measures that regulate unreasonable interferences affecting the public at large, there was less need for the application of the common law. The implementation of statutory nuisance employed to curb and regulate public nuisance with great success ultimately resulted in a decline in the use of the common law notion of public nuisance in disputes.

For the reasons set out above there is a great deal of doubt regarding the legitimacy of applying public nuisance principles in South African law. However, from 2009 to 2011 three cases were decided with reference to public nuisance, namely Intercape Ferreira Mainliner (Pty) Ltd and Others $v$ Minister of Home Affairs and Others 20105 SA 367 (WCC) (Intercape case); 410 Voortrekker Road Property Holdings CC $v$ Minister of Home Affairs and Others 2010 (8) BCLR 785 (Voortrekker case); and Growthpoint Properties Ltd $v$ SA Commercial Catering and Allied Workers Union 2011 (1) BCLR 81 (KZD) (Growthpoint Properties case), which suggests the presence of genuine public nuisance disputes. By genuine public nuisance disputes, I refer to nuisance that affected the public at large and emanated on public land such as, for instance, a street. The aim of the case note is to analyse these three cases and determine whether the notion of public nuisance has a legitimate purpose in 21 st century South African law (the Intercape and Voortrekker cases will hereafter be referred to as the fourth series of cases).

\section{Intercape, Vootrekker and Growthpoint Properties}

\section{Intercape}

To establish the existence of a public nuisance in the cases Intercape, Voortrekker and Growthpoint Properties, the logical point of departure would be to analyse the facts. Paramount to this investigation are two requirements inherently connected with the presence of a public nuisance. These characteristics normally associated with public nuisance are: a) the health or wellbeing of the general public would be affected; and, importantly, b) the nuisance must have originated on public as opposed to private land or space (see the definition of a public nuisance in Church J \& Church J 'Nuisance' in Joubert WA, Faris JA \& Harms LTC (eds) LAWSA 19 (2006) 115-145 par 163). The Voortrekker case is a direct 
consequence of the judgment in Intercape and the facts of these two cases are therefore similar. However, Growthpoint Properties is a peculiar nuisance dispute. The facts of the case will be discussed below.

In the Intercape case, the first applicant (Intercape) owns or occupies various premises in the vicinity of Montreal Drive, Airport Industria, Western Cape. The first respondent is the Minister of Home Affairs. The Department of Home Affairs (DoHA) occupies a premise (Erf 115973) in Montreal Drive. Although the premises are used by the DoHA, the Department of Public Works leases the property from Cila, which is the third respondent. Therefore the Minister of Public Works was joined as a respondent to the proceedings. Intercape, together with the other applicants (who also either owned or rented premises in the same vicinity), sought an interdict prohibiting the DoHA from using their premises as a refugee office (Intercape case par 1). The applicants argued that the refugee office contravened the City's zoning scheme. Furthermore, the applicants argued that the refugee office constituted a common law nuisance, a point which is especially relevant for the purposes of this article (Intercape case par 2). The respondents and Cila opposed the application.

Before dealing with the two questions - namely, whether the refugee office contravened the City's zoning scheme and whether a common law nuisance was constituted - the appalling conditions complained of, which were a direct consequence of the refugee office, have to be analysed.

According to the first applicant, Mr Ferreira, the DoHA's activities seriously interfered with the applicant's business. On a working day, it was likely that four to five hundred asylum seekers would visit the refugee office. The DoHA's officials only allowed a certain number of visitors into the premises per day and, as a result, many asylum seekers congregated on the streets. Furthermore, some of them slept outside the refugee office to be in the front for the next day's queue. The applicants complained that asylum seekers on the street were responsible for litter, left-over food, make-shift materials (for instance; corrugated iron) and, in the absence of toilet facilities, human waste (par 35). The applicants also complained that the general litter and, especially, the absence of toilet facilities are a major health concern for all those in the vicinity.

Furthermore, the presence of the asylum seekers in turn attracted illegal street vendors, which added to the litter generated by the crowds. Criminal elements were also attracted and asylum seekers were robbed from time to time (par 36). Criminal elements precipitated violence between themselves and the crowd. Traffic flow within Montreal Drive increased, seeing that asylum seekers were transported to the refugee office by taxis and cars. As a result, vehicles parked as they pleased and thus violated traffic laws (par 38).

The large crowds, hooting of taxis and loud music from car stereos significantly increased the noise levels outside the refugee office. In the 
case of violent outbursts, there is also an increased level of noise. Megaphones used by officials to organise crowds also contributed to the high noise levels (par 40).

Finally, the applicants argued that the safety and security of their employees was endangered. Some employees travelling to and from work on foot had been victims of robberies, muggings and intimidation, with some even resigning from their respective places of employment. Moreover, these conditions deterred clients from visiting the applicants' premises (par 45).

After having received substantial evidence and having conducted an analysis of the founding, answering and replying affidavits, the court finally adjudicated on the issue of whether the refugee office contravened the City's zoning scheme. On this issue, the court found that the refugee office did indeed contravene the City's scheme. In essence, the court concluded that Montreal Drive is subject to the Land Use and Planning Ordinance 15 of 1985 (LUPO) and that the scheme was zoned for "industrial general" purposes (par 91). The court found that it was common cause that the activities of the refugee office did not fall within the "predominant uses for this site as required by LUPO (par 91).

The most interesting and relevant part of the judgment, for the purposes of this note, is the issue of whether a nuisance was constituted. While the court was ready to grant relief on the basis that the zoning scheme had been contravened, it still addressed the cause of action based on nuisance (par 141). Without identifying which of the two categories of nuisance would be applicable, the court accepted that the alleged nuisance was of a private nature when it stated:

In the context of the present case, the term nuisance connotes a species of delict arising from wrongful violation of the duty which our common law imposes on a person towards his neighbours, the said duty being the correlative of the right which his neighbours have to enjoy the use and occupation of their properties without unreasonable interference (par 142).

Subsequent to the statement above, the court formulated the question of whether the DoHA was using Erf 115973 in a way which resulted in an unreasonable interference in the right of neighbouring owners and occupants to use their premises (par 147).

The court accepted the material evidence provided by the applicants. The evidence was not convincingly disputed by the respondents and as a consequence, the court found in favour of the applicants. Illegal parking, blocking of roads, noise, violence, crowd numbers in the street, litter (including human waste) and endangering the safety and security of the general public were all given as material evidence. Video and sound recordings provided further compelling evidence such as the outburst of violence, noise, large crowds congesting the streets, illegal parking, appalling litter and the state of mobile toilets (par 151). 
On the basis of this compelling evidence, the court further accepted that due to the presence of a large crowd on a daily basis, there was a continued nuisance in the form of noise, litter, etc. The respondents argued that they cannot be held liable for the large crowds, because the onus rests upon the law enforcement officials to deal with illegal activities in the street. However, the court concluded that the origin of the congested streets was the operation of the refugee office. The court further held that, even if it was the law enforcement officials' responsibility, it would be impossible for them to deal with circumstances in Montreal Drive on a daily basis (par 154). Even if the law enforcement officials had endless resources, their presence would by no means eliminate the unsatisfactory conditions under which the applicants are currently operating (par 154).

The court then shifted its focus to the facts of the East London case to compare it with those in the Intercape case. In the East London case, the facts clearly indicated that nuisance-causing actions originated on the respondent's property, which caused infringements on the applicant's private land; this cannot be said about the facts in the Intercape case. In the Intercape case, the nuisance was a result of the operation of a refugee office on private land, but caused a nuisance or infringement on public as opposed to private land. The judge recognised this distinction, but said, in his own words, "as a matter of principle I do not think this distinction matters" (par 156). This is a rather dubious statement, seeing that the court's misjudgement had some negative implications on the decision. There is a distinct difference between a private and a public nuisance. There are many similarities, but at the same time important differences. This issue will be dealt with in more detail in the concluding section of this note.

The court recognised that the central element, namely "reasonableness," is the same in both South African and English common law (par 157 and 163). The court concluded that an individual's actions may give rise to an actionable nuisance, even though the nuisance is caused by other persons who are attracted to the premises and congregate in the streets (par 167-168).

In conclusion, the court found that the actions emanating from the operation of the refugee office constituted a nuisance. The court granted an interdict as an order to cease the operation of the office. The court, however, suspended the interdict and allowed the DoHA to find alternative premises (par 171-186).

\section{Voortrekker}

The second case, namely the Voortrekker case, is a direct consequence of the Intercape decision. After Intercape, the DoHA relocated to premises in Maitland. After moving from their premises in the Airport Industria, the DoHA occupied alternative refugee offices in Maitland. Once again the 
applicants argued that the refugee office contravened the City of Cape Town's zoning regulations and created a nuisance.

Similar to Intercape, the court found that the operation of the refugee office contravened the zoning scheme and thus constituted a nuisance (par 78-81). Once again, the court failed to distinguish between a private and a public nuisance.

Again, the court granted an interdict to cease the operation of the refugee office, but this time the court gave the DoHA time to address illegalities and thereby regulate the operation of the office at its current location as opposed to finding alternative accommodation. The court was of the opinion that it would be impractical to close the refugee office immediately.

\section{Growthpoint}

In the latest case, namely the Growthpoint Properties case, it appears that the court might have missed yet another opportunity to clearly indicate the distinction between a private and a public nuisance. In this case, the applicant (Growthpoint) alleged that a group of Dis-Chem employees, participating in a strike organised by the South African Commercial Catering and Allied Workers Union (SACCAWU), constituted a public nuisance (par 1). According to Growthpoint, the strikers would sing, shout, ululate and make use of instruments which in effect constituted an intolerable noise. Growthpoint sought an interdict prohibiting the strikers from doing so (par 5).

The main issue in this judgment was to confirm a rule nisi granted on 3 June 2010. The court a quo granted an interim order prohibiting the strikers to sing, shout, ululate and use instruments to make a noise. For the purposes of this note, the focus is on the issue of whether a public nuisance was constituted. Growthpoint contended that by committing a nuisance the union SACCAWU and its members subjected themselves to criminal sanctions in terms of the by-laws of the city. Growthpoint further contended that they (and the other tenets of the shopping centre) had the right not be arbitrarily deprived of their use of the property. They based their premise on the right that landowners and land occupiers have the right to reasonable enjoyment of their land (the applicant relied on the East London case to substantiate the argument that a public nuisance was constituted (see Growthpoint Properties case (par 31))). Growthpoint alleged that an interference with such a right creates a public nuisance. On the issue of whether the municipal by-laws were contravened, the court found that the applicants could not provide compelling evidence to substantiate this argument. More importantly, on the issue of whether a public nuisance was constituted, the court did not make any findings.

However, to solve the question of whether a nuisance was constituted, the court decided to balance the constitutional rights of owners and occupiers to their property, the environment and trade, on the one hand, and the right of strikers to freedom of expression, to bargain collectively, 
to picket, protest and demonstrate peacefully, on the other. This method of balancing the right of the owner and that of the strikers - as a means to establish whether a nuisance was present - circumvented the basic investigation into the nature of the nuisance: For instance, whether the nuisance took place on private or public land or space; were the individuals affected by nuisance of a private or public nature? These questions could only have been answered if the court distinguished between a private and a public nuisance, thereby establishing which form of nuisance was at hand. The distinction between private and public nuisance will be elaborated on in the conclusion.

Consequently, the court found that SACCAWU and its members had to exercise their rights reasonably without interfering with Growthpoint, its tenants and the public (par 60). Therefore, the effect of the remedy was to ensure that SACCAWU and its members lower their noise levels (par 61).

One could argue that a public nuisance was constituted, but due to a lack of evidence and arguments on the side of the applicants and the court's failure to investigate the nature of the nuisance, the matter was never addressed in detail.

\section{Comments}

\section{Distinction between Private and Public Nuisance}

Although in both the Intercape and Voortrekker cases, the courts were correct to conclude that a nuisance was constituted, they erred when they automatically assumed, without relying on the facts to establish the character of the nuisance, that the unreasonable activities constituted a private nuisance. Similarly, in Growthpoint Properties, the applicant alleged the infringement of its reasonable use and enjoyment of land as a landowner. This allegation relates to a neighbour law dispute and therefore a private as opposed to a public nuisance. But Growthpoint alleged that an interference with such a right creates a public nuisance. The court never considered determining which of the two species of nuisance was constituted; instead it allowed the interchangeable use of private and public nuisance. Therefore, the courts failed to distinguish between a private and a public nuisance.

A more logical approach would be to establish the nature of the nuisance at hand. The courts would then distinguish between a private and public nuisance, and not simply use these two distinct species of nuisance interchangeably. A private nuisance affects the reasonable enjoyment of the land of an individual (typically a neighbour) who resides in the vicinity of the neighbour (Mostert, Pope, Badenhorst, Freedman Pienaar \& Van Wyk The principles of the law of property in South Africa 132-134). A private nuisance "denotes an infringement of a neighbour's entitlement of use and enjoyment so that it affects her quality of life, i.e. ordinary health, comfort and convenience, by an on-going wrong" 
(Mostert, Pope, Badenhorst, Freedman Pienaar \& Van Wyk The principles of the law of property in South Africa 134). In the case of private nuisance, the reasonableness test is applied, namely "whether a normal person, finding him or herself in the position of the plaintiff, would have tolerated the interference concerned" (Badenhorst, Pienaar, Mostert, Silberberg \& Schoeman The law of property 112). A successful applicant is entitled to an interdict (according to Church \& Church "Nuisance" in Joubert, Faris \& Harms (eds) LAWSA 19 (2006) 115-145 par 198, an interdict "can serve to restrain an offender from establishing a threatened nuisance or from continuing an existing nuisance") or an abatement order (An abatement order occurs when "a local authority or public officers are authorised under national or regional legislation to order owners or occupiers of land or premises to abate nuisances upon their property"). See Church \& Church "Nuisance" (supra par 197), self-help (according to Church \& Church "Nuisance" (supra par 196), self-help occurs only in exceptional circumstances, where an affected landowner is eligible to take the "law into his or her own hands; however, it is only available in the most urgent cases of necessity and in ordinary cases resort to selfhelp is not justifiable". Examples of urgent cases include imminent risk to health or circumstances so pressing as to admit of no delay in abating the nuisance), or claim for damages (see Church \& Church "Nuisance" (supra par 202). On the other hand, a public nuisance can be defined as "an act or omission or state of affairs that impedes, offends, endangers or inconveniences the public at large" (Church \& Church "Nuisance" (supra par 163). The doctrine was originally used for the abatement of ordinary public nuisances (protecting the general public health and safety) such as smoke (Redelinghuys and Others $v$ Silberbauer $18744 \mathrm{~B}$ 95); noise (London \& South African Exploration Co $v$ Kimberly Divisional Council (1887) 4 HCG 287); and smells ( $R$ v Le Rot (1889-1890) 7 SC 7). These kinds of nuisances can be private nuisance too, but are categorised as a public nuisance when they originate from a public space or on public land. No reasonableness test is applied to determine whether a public nuisance was constituted. The perpetrator's action is unlawful if he or she is found guilty of causing injury, damage or inconvenience to the health and safety of the general public. Currently, the perpetrator's action is unlawful if it is found to be in conflict with certain statutory regulations. An interdict or abatement order is used to suppress or stop a public nuisance.

Therefore, it was essential that the courts distinguish between these two species of nuisance to avoid the interchangeable use thereof and in so doing circumvent any confusion between the nature of a private and a public nuisance.

\section{Existence of a Genuine Public Nuisance}

It was clear from the evidence in Intercape and Voortrekker that it was not only the applicants but anyone - for example, clients, employees and visitors - who set foot in the vicinity of the refugee office would be negatively affected by having to endure noise, face the possibility of 
being mugged and robbed, be exposed to a health risk and be prevented from using the road as a result of illegal parking or road blockage. Similarly in Growthpoint Properties, it can also be argued that alleged public nuisance existed. According to van der Walt (van der Walt The Law of Neighbours (2010) 51-52; see n 87 in van der Walt JQR Constitutional Property Law 2011 (1) at 2.4):

$[T]$ he nuisance would probably have been the threat that the noise posed to the health and safety of the owners, occupiers and customers of the shopping mall. Although the shopping mall is of course private property it may well be assumed, partly on the basis of public accommodations doctrine, that the open spaces such as the entrances, parking areas and corridors of a shopping complex are sufficiently open to and used by the public that a threat or danger for public health and safety caused there could be adjudicated on the basis of public nuisance.

Abrams and Washington view a public right as (Abrams \& Washington "The misunderstood law of public nuisance: A comparison with private nuisance twenty years after Boomer" (1990) 54 Albany Law Review 359399 364):

[a] public nuisance does not necessarily involve an interference with the private enjoyment of property; rather the interference is with a public right, usually relating to public health and safety or substantial inconvenience or annoyance to the public.

Based on this view, one can ascertain that the nuisance affected a public right and not necessarily a private right. Furthermore, the nuisance occurred in a public space, namely the street. A street is a place where the community at large can be in contact with the alleged unreasonable interferences. In fact, the first series of South African public nuisance cases covered the majority of unreasonable interferences complained of in both the Voortrekker and Intercape cases, namely pollution (see $R \mathcal{V} C P$ Reynolds 190122 NLR), noise (London \& South African Exploration Co $v$ Kimberly Divisional Council 18874 (HCG) 287) and the obstruction of roads occurred in a public space or public land (see Putt $v R 1908$ (EDC) 23; Coetzee $v R 1911$ (EDL) 339). Similarly in Growthpoint Properties, parking areas, entrances and open spaces associated with the public accommodations doctrine affected a public as opposed to a private right. Therefore the nuisance complained of was a public nuisance and not a private nuisance.

These series of cases - in the period between the inception of the public nuisance doctrine into South African law and 1943 (categorised as the first series of cases) - rightfully categorised these interferences as a public nuisance after having analysed the facts in the particular context. One can therefore reach the conclusion that the court erred in assuming that a private instead of a public nuisance had been constituted. The nuisance originated in a public space, namely the street, or in the case of Growthpoint Properties, parking areas, entrances and open spaces. 
As already indicated, the judgments can be criticised for failing to distinguish between the categories of nuisance but, more importantly, that they missed the opportunity to apply the public nuisance doctrine for its original purposes, especially after its indirect application in the third series of public nuisance case law, briefly referred to above. As indicated above, these original purposes were applied in the first series of South African public nuisance case law. On the other hand, these cases illustrate that public nuisance could still, depending on the situation, have a purpose to fulfil in South African law.

\section{Nuisances Regulated by Statute}

In both the Intercape and Voortrekker cases, the unreasonable interferences complained contravened the provisions of LUPO. As a result, the courts granted an interdict that obliged the DoHA to cease the unlawful operation of the refugee office. However, in Voortrekker - in contradiction to the Intercape decision - the court gave the DoHA an option to address illegalities and thereby regulate the operation of the office at its current location, as opposed to finding alternative accommodation. The court was of the opinion that it would be impracticable to close the refugee office immediately. In essence, LUPO (in this specific scenario) replaced the use of the public nuisance doctrine.

Similarly, in the Growthpoint Properties case, if the court applied the Labour Relations Act 66 of 1995, the doctrine of public nuisance would not have been applied seeing that certain provisions in the Act would have prohibited the continuance of the alleged nuisance. This raises the question of whether the application of public nuisance was necessary or relevant at all. Therefore, it could be argued that although genuine public nuisance is constituted, the doctrine is only applicable in the absence of statutory or any other legislation such as LUPO, which covers existing or future public nuisance offences.

\section{Conclusion}

In all three cases it appears that a genuine public nuisance was constituted. In essence, the courts were correct in finding the existence of a nuisance. However, the courts erred in automatically assuming that there is no need to distinguish between a private and public nuisance. Based on the facts of each case, this distinction is paramount in order to classify a nuisance as either private or public. In these cases it was clear that a public instead of a private nuisance had been constituted.

In these cases, the courts assumed a position without investigating the nature of the nuisance. It therefore failed to correctly classify the nuisance at hand. There was no need for a rigorous investigation; a mere enquiry into the two distinct classifications of nuisance, their definitions and an analysis of case law would have sufficed to determine the category of nuisance. 
Based on the facts in the Intercape and Voortrekker cases, any individual (for example, client, employee, a motorist driving along Montreal Drive, pedestrian) who set foot in the vicinity of the refugee office was affected by the noise, violence, litter and street blockages. Thus the general public at large could be a victim of these unlawful actions such as violence, litter, health risks, noise and a blocked street in Montreal Drive, which could affect their health and safety. In the Growthpoint Properties case, although the shopping centre is privately owned, it is a public attraction. Therefore, not only those who own or rent a space in the centre are affected by noise, but anyone who comes into contact with this public space, namely the general public. Moreover, based on the public accommodations doctrine referred to by van der Walt, there is a much stronger argument that a public nuisance was constituted.

More compelling evidence of the existence of a public nuisance, as opposed to a private nuisance, is that the first series of public nuisance case law compared with the last three cases (categorised as the fourth series of cases) is similar, because the infringements complained of namely pollution, noise, blocked roads - are present in both series of cases. More importantly, all the nuisances in the first and fourth series of cases occurred in a public as opposed to a private land or space.

As stated above, this would have been an appropriate occasion to set the record straight pertaining to the application of nuisance, especially in the light of the indirect use of public nuisance in the second and third series of public nuisance cases.

In all three cases there were legislative measures to regulate interferences - which amounted to a public nuisance - at hand. This surely raises the question whether the application of public nuisance was necessary or relevant at all. It could be argued that although genuine public nuisance is constituted, the doctrine is only applicable in the absence of statutory or any other legislation such as LUPO, which covers existing or future public nuisance offences.

In essence, courts ought to distinguish between the two distinct species of private and public nuisance when determining the nature of the nuisance in a particular situation. The nature of the nuisance has to be determined in order to establish which nuisance is present and; finally, the doctrine can only be applied in the absence of any legislation regulating such interferences.

Furthermore, I am of the opinion that the notion of public nuisance can still serve a legitimate purpose in South African law. But it should be applied only in the absence of legislation covering nuisance offences.

A SAMUELS

University of the Western Cape 